\title{
EFFECT OF BIO-STIMULANTS (HUMIC ACID, SALICYLIC ACID AND CHITOSAN) ON ROSE PERIWINKLE (CATHARANTHUS ROSEUS L.)
}

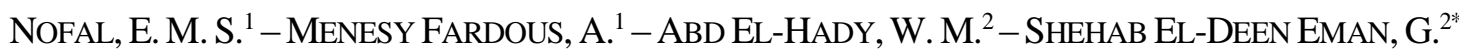 \\ ${ }^{I}$ Hort. Dept., Agric. Fac., Kafr El-Sheikh Univ., Kafr El-Sheikh, Egypt \\ ${ }^{2}$ Ornamental Plants and Landscape Gardening Research Department, Horticulture Research \\ Institute, Agriculture Research Center, Giza, Egypt \\ *Corresponding author \\ e-mail: shehabeldin.iman@yahoo.com
}

(Received $2^{\text {nd }}$ Apr 2020; accepted $7^{\text {th }}$ Oct 2020)

\begin{abstract}
The present research was conducted during two successive seasons of 2017 and 2018 at the green house of the Horticulture Research Station, Mansoura, Egypt (31 ${ }^{\circ} 2^{\prime} 4$ ” N - 31 ${ }^{\circ} 23^{\prime} 42^{\prime \prime}$ E) to study the influence of some bio-stimulants (humic acid, salicylic acid and chitosan) on vegetative and rooting growth parameters as well as some chemical constituents of a local variety of Catharanthus roseus L. (Vinca rosae, G. Don) (Periwinkle). The treatments involved ten applications i.e. control treatment, humic acid at 2,4 and $6 \mathrm{ml} / \mathrm{l}$, salicylic acid at 100,150 and $200 \mathrm{mg} / \mathrm{l}$ and chitosan at 100, 200 and $300 \mathrm{mg} / \mathrm{l}$. They were performed six times at fortnightly intervals during the two growing seasons under greenhouse conditions $\left(25 \pm 1{ }^{\circ} \mathrm{C}\right.$ and $40-50 \%$ R.H). The obtained results showed that all vegetative growth and root parameters, (plant height, branch No., leaf area, root length) and their fresh and dry weights were significantly increased due to the applied bio-stimulants when compared to control treatment. Likewise, the chemical constituents of chlorophyll $\mathrm{a}$ and $\mathrm{b}$ in the leaves as well as their $\mathrm{N}, \mathrm{P}$ and $\mathrm{K} \%$ and total alkaloids also experienced a gain. The best results were provided by chitosan treatments at the rates of 300 and $200 \mathrm{mg} / \mathrm{l}$, followed by humic acid at $6 \mathrm{ml} / \mathrm{l}$ then salicylic acid at $200 \mathrm{mg} / \mathrm{l}$.
\end{abstract}

Keywords: bio-fertilizer, deacetylchitin, fulvic acid and antioxidant 2-hydroxybenzoic acid, periwinkle

\section{Introduction}

Catharanthus roseus L. (Vinca rosae G. Don) from the family of Apocynaceae is native and endemic in Madagascar, other English terms occasionally used include, Cape periwinkle, rose periwinkle, rosy periwinkle and "old maid" periwinkle (Fig. 1). It has long been cultivated as a herbal medicine and ornamental annual summer plant in flower beds and flower border, as they can grow up to $1 \mathrm{~m}$ tall with oval to oblong leaves and while the flowers are creamy or pink with red center, the fruit is a pair of follicles. It is well known in folk medicine for the treatment of diabetes (Harridy, 1986) and for anti-cancer treatments (Nejat et al., 2015).

The bio-stimulants are a category of relatively new products of diverse formulations that positively affect plants vital processes (Calvo et al., 2014).

Humic substances are the most widely distributed organic products of biosynthesis on the face of earth, exceeding the amount of carbon contained in all living organisms by approximately one order of magnitude. The major functional groups of humic acid include carboxyl, phenolic hydroxyl, alcoholic hydroxyl, ketone and quinoid (Russo and Berlyn, 1990). The mechanism of humic acid in promoting plant growth is thought to be related to the increase in cell membrane permeability, oxygen uptake, respiration, photosynthesis, phosphorus uptake, and root cell elongation as plant growth factors proposed by many authors to explain the promotive effect of humic acid on such plant 
measurement (Cacco and Dell Agnolla, 1984 and Russo and Berlyn, 1990). In addition, humic acid has beneficial effects on soil structure, its chemical properties and its content of the available microrganisms that increase nutrient uptake and particularly important for transportation and availability of micronutrients (Bohme and Thi lua, 1997).

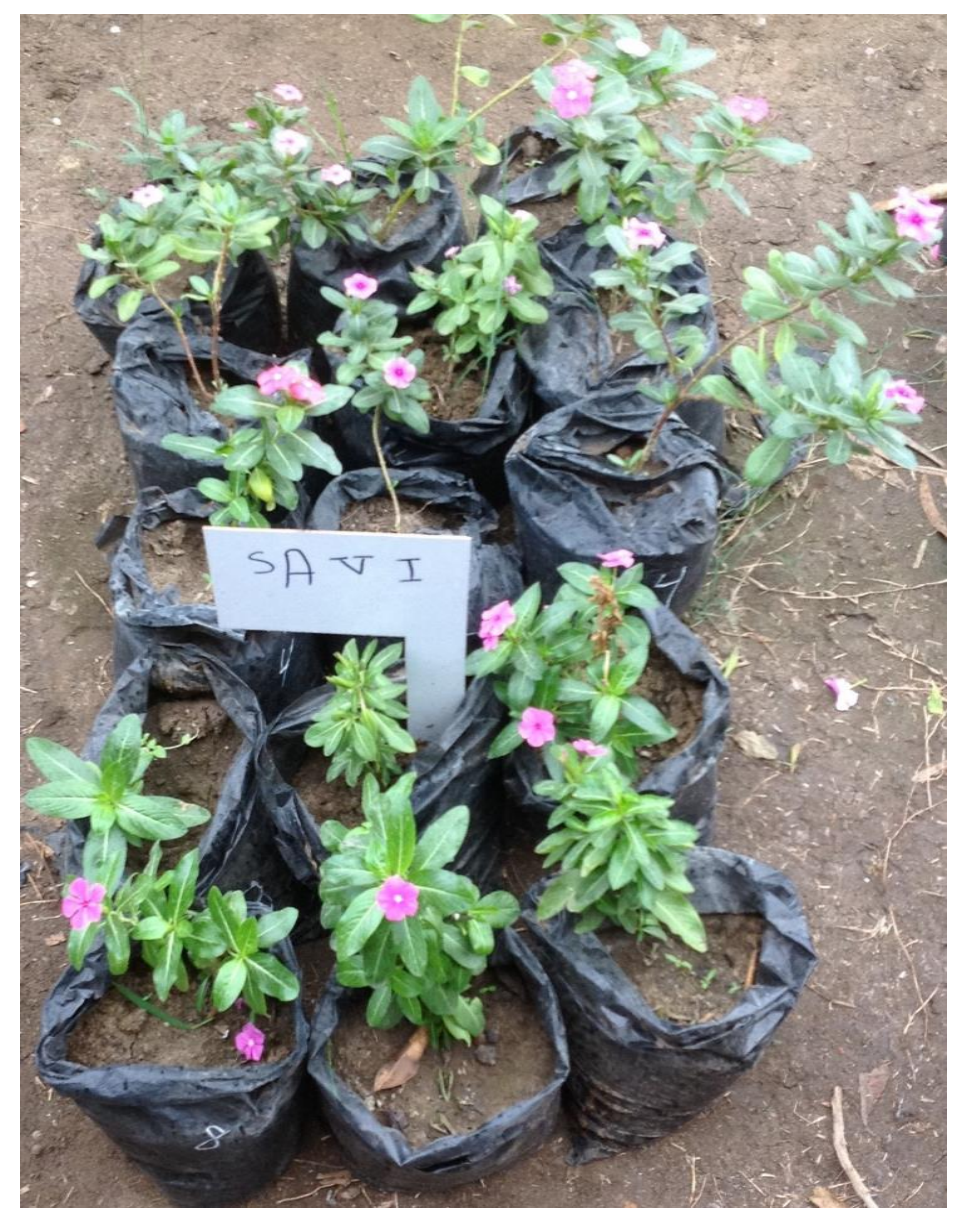

Figure 1. Catharanthus roseus L.

Salicylic acid is a phenolic phytohormone found in plants with the beneficial roles of stimulating photosynthesis, ion uptake and transport and as antioxidant against free radical ions to protect plant cell from damage. In addition, it regulates some aspects of disease resistance in plants (Volt et al., 2009).

Chitosan is a natural biopolymer of seed weed extract that stimulate nutrient's uptake, photosynthesis and increase chlorophyll content, increases the availability and uptake of water and nutrients and enzyme activities that influence plant growth and development (Guan et al., 2009), besides cell enlargement (Malekpoor et al., 2016 and Salahna et al., 2017).

Therefore, due to the economic importance of bio-stimulates, the present study was designed to find out the response of Chatharanthus roseus growth to different levels of humic acid, salicylic acid and chitosan. 


\section{Materials and methods}

The present experiments were conducted in the greenhouse of Horticulture Research Station at Mansoura (120 km at North of Nile Delta) (31 ${ }^{\circ}$ ' 4" N - 31 23 '42" E) Egypt during two successive seasons of 2017 and 2018 as the first season was replicated in the second one to refine the obtained results, which is a common procedure in Egypt. The aim was to detect the effect of different levels of some biostimulants on the vegetative and rooting growth of periwinkle besides its contents of some chemical constituents.

Seeds of a local variety of periwinkle blackish color with pyriform to obviate shape, were planted in trays (on March) and after one month the obtained transplants were transplanted in plastic pots of $8 \mathrm{~cm}$ diameter as one plant/pot filled with sand and silt at 1:1 (v/v). Two months later the plants, were transplanted in $25 \mathrm{~cm}$ diameter plastic pots of grey color and filled with the same soil mixture with the addition of monocalcium phosphate $\left(\mathrm{CaH}_{4} \mathrm{P}_{2} \mathrm{O}_{8}\right)$ at $50 \mathrm{mg} /$ pot and disinfected with a local fungicide (No-Blight) and watered whenever needed.

Humic acid was added with irrigation water as preferable method for such compound at levels of 2, 4 and $6 \mathrm{ml} / \mathrm{l}$. However, salicylic acid was foliar sprayed at 100, 150 and $200 \mathrm{mg} / \mathrm{l}$ while chitosan was foliar sprayed at 100, 200 and $300 \mathrm{mg} / \mathrm{l}$. The foliar spraying was conducted to run off plants. This made 9 treatments in addition to the control treatment (check treatment) without any additions in a complete randomized design without interaction in 3 replicates (each replicate contained 10 plants).

At the end of every season (on November 5th) the following parameters were recorded: a) Vegetative growth (plant height $(\mathrm{cm})$, No branches/plant, leaf area $\left(\mathrm{cm}^{2}\right)$ (calculated by CI-202 Portable Laser Leaf Area Meter (CID Bio-Science Made In USA) besides the fresh and dry weights of the aerial parts of the plant. b) Root length $(\mathrm{cm})$ and the fresh and dry weights of the roots (g)/plant. c) Some chemical composition parameters of a certain leaf on the plant median part as (1) $\mathrm{N} \%$ in the dried leaf according Chapman and Pratt (1978), (2) P\% in the dried leaf by the method of A.O.A.C. (1980), (3) K\% in the dried leaf according to Jackson (1973), (4) Chlorophyll $\mathrm{a}$ and $\mathrm{b}$ content in the fresh leaf (mg/g f.w.) according to Krishnan et al. (1996), (5) Total alkaloids \% was done according to Masoud et al. (1968).

The experimental layout was split plot design. Statistical analysis: Data were statistically analyzed using analysis of variance (ANOVA) and the means of treatments were compared using L.S.D test at 5\% (Steel and Torrie, 1980) with the statistical package program, SPSS.

\section{Results}

\section{Vegetative growth parameters and fresh and dry weights of the aerial plant parts}

Data presented in Table 1 revealed that all bio-stimulant treatments significantly increased plant height, branch No/plant and leaf area over control. The significantly tallest plants resulted from the treatment of chitosan at either 200 or $300 \mathrm{ppm}$ as there were non-significant differences in between in the two seasons. This was followed with significant differences by the treatment of humic acid at $6 \mathrm{ml} / 1$ then the treatment of salicylic acid at $200 \mathrm{mg} / \mathrm{l}$. A somewhat similar trend was obtained for branch No/plant with exception for the treatment of $300 \mathrm{ppm}$ chitosan which gave significantly higher values than the control in both seasons. 
For leaf area the significantly highest records were obtained from the treatment of $300 \mathrm{ppm}$ chitosan followed with chitosan treatment at $200 \mathrm{ppm}$ with significant differences in between in the first season while one the differences were insignificant in the second. Other biostimulant treatments gave significantly less values in this concern.

Table 1. Effect of humic acid, salicylic acid and chitosan on some vegetative growth parameters and fresh and dry weight of plants in two seasons of Periwinkle

\begin{tabular}{|c|c|c|c|c|c|}
\hline Treatments & $\begin{array}{c}\text { Plant height } \\
(\mathrm{cm})\end{array}$ & $\begin{array}{c}\text { No. of } \\
\text { branches/plant }\end{array}$ & $\begin{array}{c}\text { Fresh weight of aerial } \\
\text { plants parts (g) }\end{array}$ & $\begin{array}{c}\text { Dry weight } \\
\text { parts/plant }(g)\end{array}$ & $\begin{array}{c}\text { Leaf area } \\
\left(\mathrm{cm}^{2}\right)\end{array}$ \\
\hline \multicolumn{6}{|c|}{ First season (2017) } \\
\hline Control & $22.52 \mathrm{~h}$ & $4.33 \mathrm{~g}$ & $11.98 \mathrm{~g}$ & $2.09 \mathrm{~g}$ & $11.25 \mathrm{j}$ \\
\hline $\begin{array}{l}\text { Humic acid } 2 \mathrm{ml} / 1 \\
\text { Humic acid } 4 \mathrm{ml} / 1 \\
\text { Humic acid } 6 \mathrm{ml} / 1\end{array}$ & $\begin{array}{l}26.62 \mathrm{f} \\
31.34 \mathrm{~d} \\
37.64 \mathrm{~b}\end{array}$ & $\begin{array}{c}6.67 \mathrm{f} \\
8.00 \mathrm{de} \\
9.67 \mathrm{bc}\end{array}$ & $\begin{array}{l}14.55 \mathrm{f} \\
17.45 \mathrm{de} \\
21.37 \mathrm{~b}\end{array}$ & $\begin{array}{c}2.69 \mathrm{ef} \\
3.45 \mathrm{~cd} \\
4.54 \mathrm{~b}\end{array}$ & $\begin{array}{l}13.24 \mathrm{~h} \\
14.64 \mathrm{f} \\
17.12 \mathrm{c}\end{array}$ \\
\hline $\begin{array}{l}\text { Salicylic acid } 100 \mathrm{mg} / \mathrm{l} \\
\text { Salicylic acid } 150 \mathrm{mg} / \mathrm{l} \\
\text { Salicylic acid } 200 \mathrm{mg} / \mathrm{l}\end{array}$ & $\begin{array}{l}24.55 \mathrm{~g} \\
29.12 \mathrm{e} \\
35.29 \mathrm{c}\end{array}$ & $\begin{array}{l}5.00 \mathrm{~g} \\
7.00 \mathrm{ef} \\
8.67 \mathrm{~cd}\end{array}$ & $\begin{array}{c}13.16 \mathrm{fg} \\
16.28 \mathrm{e} \\
20.38 \mathrm{bc}\end{array}$ & $\begin{array}{l}2.39 \mathrm{fg} \\
3.11 \mathrm{de} \\
4.40 \mathrm{~b}\end{array}$ & $\begin{array}{l}12.72 \mathrm{i} \\
14.03 \mathrm{~g} \\
16.26 \mathrm{~d}\end{array}$ \\
\hline $\begin{array}{l}\text { Chitosan } 100 \mathrm{mg} / \mathrm{l} \\
\text { Chitosan } 200 \mathrm{mg} / \mathrm{l} \\
\text { Chitosan } 300 \mathrm{mg} / \mathrm{l}\end{array}$ & $\begin{array}{l}33.51 \mathrm{c} \\
40.50 \mathrm{a} \\
41.91 \mathrm{a}\end{array}$ & $\begin{array}{c}8.33 \mathrm{~d} \\
10.33 \mathrm{~b} \\
12.00 \mathrm{a}\end{array}$ & $\begin{array}{l}18.96 \mathrm{~cd} \\
23.50 \mathrm{a} \\
24.52 \mathrm{a}\end{array}$ & $\begin{array}{c}3.73 \mathrm{c} \\
4.70 \mathrm{ab} \\
5.15 \mathrm{a}\end{array}$ & $\begin{array}{l}15.32 \mathrm{e} \\
18.16 \mathrm{~b} \\
18.95 \mathrm{a}\end{array}$ \\
\hline LSD $5 \%$ & 1.85 & 1.32 & 1.66 & 0.51 & 0.17 \\
\hline \multicolumn{6}{|c|}{ Second season (2018) } \\
\hline Control & $24.32 \mathrm{f}$ & $5.67 f$ & $12.70 \mathrm{~g}$ & $2.31 \mathrm{~g}$ & $11.19 \mathrm{~g}$ \\
\hline $\begin{array}{l}\text { Humic acid } 2 \mathrm{ml} / 1 \\
\text { Humic acid } 4 \mathrm{ml} / 1 \\
\text { Humic acid } 6 \mathrm{ml} / 1\end{array}$ & $\begin{array}{l}28.18 \mathrm{e} \\
33.15 \mathrm{~d} \\
40.39 \mathrm{~b}\end{array}$ & $\begin{array}{c}7.67 \mathrm{e} \\
9.00 \mathrm{~d} \\
10.33 \mathrm{c}\end{array}$ & $\begin{array}{l}16.65 \mathrm{f} \\
18.67 \mathrm{de} \\
22.31 \mathrm{~b}\end{array}$ & $\begin{array}{l}2.88 \mathrm{ef} \\
3.69 \mathrm{~cd} \\
4.81 \mathrm{ab}\end{array}$ & $\begin{array}{l}13.71 \mathrm{f} \\
15.12 \mathrm{e} \\
17.84 \mathrm{~b}\end{array}$ \\
\hline $\begin{array}{l}\text { Salicylic acid } 100 \mathrm{mg} / \mathrm{l} \\
\text { Salicylic acid } 150 \mathrm{mg} / \mathrm{l} \\
\text { Salicylic acid } 200 \mathrm{mg} / \mathrm{l}\end{array}$ & $\begin{array}{l}25.94 \mathrm{f} \\
31.19 \mathrm{~d} \\
37.34 \mathrm{c}\end{array}$ & $\begin{array}{l}6.00 \mathrm{f} \\
8.67 \mathrm{de} \\
10.33 \mathrm{c}\end{array}$ & $\begin{array}{c}14.15 \mathrm{fg} \\
17.45 \mathrm{e} \\
21.70 \mathrm{bc}\end{array}$ & $\begin{array}{c}2.56 \mathrm{fg} \\
3.33 \mathrm{de} \\
4.68 \mathrm{~b}\end{array}$ & $\begin{array}{l}13.09 \mathrm{f} \\
14.63 \mathrm{e} \\
17.18 \mathrm{c}\end{array}$ \\
\hline $\begin{array}{l}\text { Chitosan } 100 \mathrm{mg} / \mathrm{l} \\
\text { Chitosan } 200 \mathrm{mg} / \mathrm{l} \\
\text { Chitosan } 300 \mathrm{mg} / \mathrm{l}\end{array}$ & $\begin{array}{l}35.47 \mathrm{c} \\
43.33 \mathrm{a} \\
44.37 \mathrm{a}\end{array}$ & $\begin{array}{l}9.33 \mathrm{~cd} \\
11.67 \mathrm{~b} \\
14.00 \mathrm{a}\end{array}$ & $\begin{array}{c}20.30 \mathrm{~cd} \\
24.94 \mathrm{a} \\
26.65 \mathrm{a}\end{array}$ & $\begin{array}{c}4.06 \mathrm{c} \\
4.90 \mathrm{ab} \\
5.23 \mathrm{a}\end{array}$ & $\begin{array}{l}16.05 \mathrm{~d} \\
19.08 \mathrm{a} \\
19.64 \mathrm{a}\end{array}$ \\
\hline LSD 5\% & 1.98 & 1.24 & 1.73 & 0.51 & 0.64 \\
\hline
\end{tabular}

For fresh and dry weights of the aerial plant parts, all biostimulant treatments gave significantly heavier weights than control in both seasons. The significantly heaviest values resulted from the treatments of 200 and $300 \mathrm{ppm}$ chitosan in both seasons without significant differences in between. This was followed by other bio-stimulant treatments which recorded significantly less values. The significantly heaviest fresh and dry weights of the plant aerial parts due to bio-stimulant treatments are a reflection on their stimulatory effects of such compounds on the aforementioned vegetative growth parameters especially the treatments of chitosan at 200 and $300 \mathrm{ppm}$.

\section{Length of the root, fresh and dry weights of the roots per plant}

Data presented in Table 2 showed that all bio-stimulant treatments gave significantly longer roots than control. The highest values with utmost significance resulted from the treatments of chitosan at $300 \mathrm{ppm}$ followed by chitosan at $200 \mathrm{ppm}$ with significant differences between them in the first season and non-significant differences in the second one.

The other bio-stimulant treatments gave significantly less values in most cases. 
For fresh and dry weights of roots per plant, data in the same table cleared that all treatments gave significantly heavier weights than the control in both seasons.

The significantly understanding values resulted from the treatment of chitosan at $300 \mathrm{ppm}$ followed by chitosan at $200 \mathrm{ppm}$ with non-significant differences in most cases between them except for the dry weight in the second season in the treatment of $300 \mathrm{ppm}$ chitosan in the criterion of root dry weight per plant. These results are reflections of such aforementioned treatment effects on recording longer root.

Table 2. Effect of humic acid, salicylic acid and chitosan on root and fresh and dry weights/plants of periwinkle during two seasons

\begin{tabular}{|c|c|c|c|}
\hline Treatments & Root length $(\mathrm{cm})$ & Fresh weight of $\operatorname{root}(\mathrm{g})$ & Dry weight of root (g) \\
\hline \multicolumn{4}{|c|}{ First season (2017) } \\
\hline Control & $16.19 \mathrm{~h}$ & $3.58 \mathrm{f}$ & $0.65 f$ \\
\hline Humic acid $2 \mathrm{ml} / \mathrm{l}$ & $18.51 \mathrm{fg}$ & $4.70 \mathrm{def}$ & $0.94 \mathrm{e}$ \\
\hline Humic acid 4 ml/l & $21.16 \mathrm{e}$ & $5.53 \mathrm{bcd}$ & $1.20 \mathrm{~d}$ \\
\hline Humic acid $6 \mathrm{ml} / \mathrm{l}$ & $24.71 b c$ & $6.66 \mathrm{ab}$ & $1.56 \mathrm{~b}$ \\
\hline Salicylic acid $100 \mathrm{mg} / \mathrm{l}$ & $17.47 \mathrm{gh}$ & $4.18 \mathrm{ef}$ & $0.77 f$ \\
\hline Salicylic acid $150 \mathrm{mg} / \mathrm{l}$ & $19.30 \mathrm{f}$ & $5.38 \mathrm{cde}$ & $1.07 \mathrm{de}$ \\
\hline Salicylic acid $200 \mathrm{mg} / \mathrm{l}$ & $23.52 \mathrm{~cd}$ & $6.50 \mathrm{abc}$ & $1.46 \mathrm{bc}$ \\
\hline Chitosan $100 \mathrm{mg} / \mathrm{l}$ & $22.28 \mathrm{de}$ & $5.69 \mathrm{bcd}$ & $1.36 \mathrm{c}$ \\
\hline Chitosan $200 \mathrm{mg} / \mathrm{l}$ & $25.41 \mathrm{~b}$ & $7.41 \mathrm{a}$ & $1.71 \mathrm{a}$ \\
\hline Chitosan $300 \mathrm{mg} / \mathrm{l}$ & $27.51 \mathrm{a}$ & $7.52 \mathrm{a}$ & $1.84 \mathrm{a}$ \\
\hline LSD $5 \%$ & 1.81 & 1.26 & 0.14 \\
\hline \multicolumn{4}{|c|}{ Second season (2018) } \\
\hline Control & $17.13 \mathrm{~h}$ & $3.75 \mathrm{f}$ & $0.69 \mathrm{i}$ \\
\hline Humic acid $2 \mathrm{ml} / \mathrm{l}$ & $19.55 \mathrm{fg}$ & $4.95 \mathrm{def}$ & $1.00 \mathrm{gh}$ \\
\hline Humic acid 4 ml/l & $22.17 \mathrm{de}$ & $5.83 \mathrm{bcd}$ & $1.29 \mathrm{ef}$ \\
\hline Humic acid 6 ml/l & $26.01 \mathrm{~b}$ & $7.08 \mathrm{ab}$ & $1.66 \mathrm{bc}$ \\
\hline Salicylic acid $100 \mathrm{mg} / \mathrm{l}$ & $18.03 \mathrm{gh}$ & $4.44 \mathrm{ef}$ & $0.85 \mathrm{~h}$ \\
\hline Salicylic acid $150 \mathrm{mg} / \mathrm{l}$ & $20.30 \mathrm{ef}$ & $5.66 \mathrm{cde}$ & $1.13 \mathrm{fg}$ \\
\hline Salicylic acid $200 \mathrm{mg} / \mathrm{l}$ & $24.59 b c$ & $6.48 b c$ & $1.54 \mathrm{~cd}$ \\
\hline Chitosan $100 \mathrm{mg} / \mathrm{l}$ & $23.45 \mathrm{~cd}$ & $6.10 \mathrm{bcd}$ & $1.43 \mathrm{de}$ \\
\hline Chitosan $200 \mathrm{mg} / \mathrm{l}$ & $26.49 b$ & $7.91 \mathrm{a}$ & $1.78 \mathrm{~b}$ \\
\hline Chitosan $300 \mathrm{mg} / \mathrm{l}$ & $28.73 a$ & $7.95 \mathrm{a}$ & $1.97 \mathrm{a}$ \\
\hline LSD $5 \%$ & 1.91 & 1.36 & 0.15 \\
\hline
\end{tabular}

\section{Some chemical composition parameters}

\section{Leaf content of chlorophyll $a$ and $b$}

Data presented in Table 3 showed that all bio-stimulant treatments significantly increased both chlorophyll a and b over control in the two seasons.

The significantly highest contents resulted from treatment of chitosan at 300 and $200 \mathrm{ppm}$ with non-significant differences between them for chlorophyll (b) while there were significant results for chlorophyll (a). The other biostimulant treatments gave significantly less values in the majority of cases.

\section{$N, P$ and $K \%$ in the leaves}

Presented data in Table 4 revealed that all bio-stimulant treatments significantly increased $\mathrm{N}, \mathrm{P}$ and $\mathrm{K} \%$ in the leaves over control in the two seasons. The significantly 
highest percentages for the three mineral elements were recorded for the treatment of chitosan at $300 \mathrm{ppm}$ followed by the treatment of chitosan at $200 \mathrm{ppm}$ with significant differences in between in all cases. However, the remainder bio-stimulant treatments recorded significantly less values.

Table 3. Effect of humic acid, salicylic acid and chitosan on the content of pigments (chlorophyll $a$ and $b$ ) of periwinkle during two seasons

\begin{tabular}{|c|c|c|}
\hline Treatments & Chlorophyll a (mg/g f.w) & Chlorophyll b (mg/g f.w) \\
\hline \multicolumn{3}{|c|}{ First season (2017) } \\
\hline Control & $0.397 \mathrm{j}$ & $0.264 \mathrm{i}$ \\
\hline Humic acid $2 \mathrm{ml} / \mathrm{l}$ & $0.443 \mathrm{~h}$ & $0.298 \mathrm{~g}$ \\
\hline Humic acid $4 \mathrm{ml} / \mathrm{l}$ & $0.487 f$ & $0.330 \mathrm{e}$ \\
\hline Humic acid $6 \mathrm{ml} / \mathrm{l}$ & $0.577 \mathrm{c}$ & $0.383 b$ \\
\hline Salicylic acid $100 \mathrm{mg} / \mathrm{l}$ & $0.414 \mathrm{i}$ & $0.285 \mathrm{~h}$ \\
\hline Salicylic acid $150 \mathrm{mg} / \mathrm{l}$ & $0.472 \mathrm{~g}$ & $0.317 \mathrm{f}$ \\
\hline Salicylic acid $200 \mathrm{mg} / \mathrm{l}$ & $0.537 \mathrm{~d}$ & $0.365 c$ \\
\hline Chitosan $100 \mathrm{mg} / \mathrm{l}$ & $0.507 \mathrm{e}$ & $0.343 \mathrm{~d}$ \\
\hline Chitosan $200 \mathrm{mg} / 1$ & $0.607 \mathrm{~b}$ & $0.415 \mathrm{a}$ \\
\hline Chitosan $300 \mathrm{mg} / \mathrm{l}$ & $0.621 \mathrm{a}$ & $0.412 \mathrm{a}$ \\
\hline LSD 5\% & 0.012 & 0.006 \\
\hline \multicolumn{3}{|c|}{ Second season (2018) } \\
\hline Control & $0.412 \mathrm{j}$ & $0.275 \mathrm{i}$ \\
\hline Humic acid $2 \mathrm{ml} / \mathrm{l}$ & $0.463 \mathrm{~h}$ & $0.312 \mathrm{~g}$ \\
\hline Humic acid $4 \mathrm{ml} / \mathrm{l}$ & $0.511 \mathrm{f}$ & $0.345 \mathrm{e}$ \\
\hline Humic acid $6 \mathrm{ml} / \mathrm{l}$ & $0.596 \mathrm{c}$ & $0.404 \mathrm{~b}$ \\
\hline Salicylic acid $100 \mathrm{mg} / \mathrm{l}$ & $0.436 j$ & $0.298 \mathrm{~h}$ \\
\hline Salicylic acid $150 \mathrm{mg} / \mathrm{l}$ & $0.494 \mathrm{~g}$ & $0.333 \mathrm{f}$ \\
\hline Salicylic acid $200 \mathrm{mg} / \mathrm{l}$ & $0.563 \mathrm{~d}$ & $0.384 \mathrm{c}$ \\
\hline Chitosan $100 \mathrm{mg} / \mathrm{l}$ & $0.533 \mathrm{e}$ & $0.360 \mathrm{~d}$ \\
\hline Chitosan $200 \mathrm{mg} / \mathrm{l}$ & $0.638 b$ & $0.435 \mathrm{a}$ \\
\hline Chitosan $300 \mathrm{mg} / \mathrm{l}$ & $0.650 \mathrm{a}$ & $0.429 a$ \\
\hline LSD 5\% & 0.007 & 0.007 \\
\hline
\end{tabular}

\section{Total alkaloid \%}

The effects of the different bio-stimulants (humic acid, salicylic acid and chitosan) on total alkaloids \% of Periwinkle plant leaves are presented in Table 4. Data proved that adding the bio-substances to plants significantly increased total alkaloids $\%$ to the highest values for the treatments of chitosan at $300 \mathrm{mg}$ and $200 \mathrm{mg} / \mathrm{l}$, humic acid at $6 \mathrm{ml} / \mathrm{l}$ and salicylic acid at $200 \mathrm{mg} / \mathrm{l}$ for the $1^{\text {st }}$ and $2^{\text {nd }}$ seasons, respectively.

\section{Discussion}

The results revealed that all treatments increased and enhanced all vegetative growth parameters. These results are supported by El-Sayed et al. (2016) on Cycas, Gad et al. (2016) on Ixora coccinea and El-Khateeb et al. (2018) on Spathiphyllum wallisii.

The stimulatory effects of chitosan on the foregoing results may be due to stimulation of the availability and uptake of nutrients and water besides, the increase 
in enzyme activities required for producing the metabolites necessary for the plant growth and development.

Table 4. Effect of humic acid, salicylic acid and chitosan on minerals NPK \% and total alkaloid in the leaves of periwinkle during two seasons

\begin{tabular}{c|c|c|c|c}
\hline Treatments & N\% & P\% & K\% & $\begin{array}{c}\text { Total alkaloids } \\
\text { (mg/g d.w.) }\end{array}$ \\
\hline \multicolumn{5}{|c}{ First season (2017) } \\
\hline Control & $1.37 \mathrm{i}$ & $0.227 \mathrm{j}$ & $1.65 \mathrm{j}$ & $0.097 \mathrm{~h}$ \\
Humic acid 2 ml/1 & $1.64 \mathrm{~g}$ & $0.254 \mathrm{~h}$ & $1.93 \mathrm{~h}$ & $0.112 \mathrm{f}$ \\
Humic acid 4 ml/1 & $1.80 \mathrm{e}$ & $0.282 \mathrm{f}$ & $2.22 \mathrm{f}$ & $0.126 \mathrm{e}$ \\
Humic acid 6 ml/1 & $2.11 \mathrm{~b}$ & $0.324 \mathrm{c}$ & $2.77 \mathrm{c}$ & $0.148 \mathrm{~b}$ \\
Salicylic acid 100 mg/l & $1.52 \mathrm{~h}$ & $0.243 \mathrm{i}$ & $1.76 \mathrm{i}$ & $0.103 \mathrm{~g}$ \\
Salicylic acid 150 mg/l & $1.72 \mathrm{f}$ & $0.272 \mathrm{~g}$ & $2.11 \mathrm{~g}$ & $0.123 \mathrm{e}$ \\
Salicylic acid 200 mg/l & $2.00 \mathrm{c}$ & $0.312 \mathrm{~d}$ & $2.60 \mathrm{~d}$ & $0.142 \mathrm{c}$ \\
Chitosan 100 mg/l & $1.92 \mathrm{~d}$ & $0.293 \mathrm{e}$ & $2.41 \mathrm{e}$ & $0.135 \mathrm{~d}$ \\
Chitosan 200 mg/l & $2.16 \mathrm{~b}$ & $0.347 \mathrm{~b}$ & $2.95 \mathrm{~b}$ & $0.153 \mathrm{~b}$ \\
Chitosan 300 mg/l & $2.23 \mathrm{a}$ & $0.363 \mathrm{a}$ & $3.05 \mathrm{a}$ & $0.164 \mathrm{a}$ \\
LSD 5\% & 0.04 & 0.006 & 0.05 & 0.005 \\
\hline \multicolumn{5}{|c}{ Second season (2018) } \\
\hline Control & $1.44 \mathrm{i}$ & $0.236 \mathrm{j}$ & $1.74 \mathrm{j}$ & $0.101 \mathrm{~g}$ \\
Humic acid 2 ml/1 & $1.73 \mathrm{~g}$ & $0.266 \mathrm{~h}$ & $2.03 \mathrm{~h}$ & $0.117 \mathrm{f}$ \\
Humic acid 4 ml/1 & $1.87 \mathrm{e}$ & $0.295 \mathrm{f}$ & $2.32 \mathrm{f}$ & $0.132 \mathrm{e}$ \\
Humic acid 6 ml/1 & $2.23 \mathrm{~b}$ & $0.337 \mathrm{c}$ & $2.88 \mathrm{c}$ & $0.155 \mathrm{~b}$ \\
Salicylic acid 100 mg/l & $1.59 \mathrm{~h}$ & $0.254 \mathrm{i}$ & $1.84 \mathrm{i}$ & $0.107 \mathrm{~g}$ \\
Salicylic acid 150 mg/l & $1.79 \mathrm{f}$ & $0.286 \mathrm{~g}$ & $2.19 \mathrm{~g}$ & $0.129 \mathrm{e}$ \\
Salicylic acid 200 mg/l & $2.09 \mathrm{c}$ & $0.326 \mathrm{~d}$ & $2.74 \mathrm{~d}$ & $0.149 \mathrm{c}$ \\
Chitosan 100 mg/l & $2.00 \mathrm{~d}$ & $0.306 \mathrm{e}$ & $2.55 \mathrm{e}$ & $0.142 \mathrm{~d}$ \\
Chitosan 200 mg/l & $2.26 \mathrm{~b}$ & $0.361 \mathrm{~b}$ & $3.09 \mathrm{a}$ & $0.160 \mathrm{~b}$ \\
Chitosan 300 mg/l & $2.34 \mathrm{a}$ & $0.379 \mathrm{a}$ & $3.20 \mathrm{a}$ & $0.173 \mathrm{a}$ \\
LSD 5\% & 0.05 & 0.006 & 0.06 & 0.006 \\
\hline
\end{tabular}

Humic acid increases cell membrane permeability, oxygen uptake, respiration and nutrients uptake by plants which reflect on producing healthy plants.

Likewise, are the stimulatory effects of salicylic acid on plant growth and development. This is supported by other researchers as Malekpoor et al. (2016) on Ixora collinear and Salachna et al. (2017) on Verbena bonariensis.

All treatments increased the averages of root length, fresh and dry weights of roots. These results are in agreement with El-Khateeb et al. (2010) on Calia secundiflora plants who found that humic acid at $1 \%$ increased root length, fresh and dry weight of root. Also El-Khateeb et al. (2018) on Spathiphyllum wallisii plants stated that the foliar application of both humic acid at $1 \mathrm{ml} / 1$ and chitosan at $0.1 \mathrm{~g} / \mathrm{l}$ were the best treatments for increasing the root length. The stimulatory effects of chitosan on root growth may be due to its stimulatory influences on uptake and availability of nutrients to give healthy plants. For humic acid, it promotes root growth via improving better structure of soil texture and increasing soil microorganisms, cell enlargement and water status necessary for vigorous root growth according to Malekpoor et al. (2016). This is supported by the findings of Basil and Salachna et al. (2017) on Verbena bonariensis concerning chitosan. 
The chlorophyll $\mathrm{a}$ and $\mathrm{b}$ content increased by all treatments due to bio-stimulant treatment application is attributed to their promotive effect on photosynthesis and cell enlargement and especially foliar spraying chitosan which enhances the uptake of nutrients necessary for such process. In this concern, Hadrami et al. (2010) and Hadwiger (2013) stated that chitosan has been recognized as a product to enhance crop production due to its bioactivities, biodegradability growth stimulation and seed germination, increasing nutrients uptake, reducing oxidative stress, increasing photosynthesis, chlorophyll content and chloroplast enlargement in the leaves. The obtained results are supported with those of Castro et al. (2016) on cariader, Madhavi (2013) on isabgol and Boogar et al. (2014) on Petunia hybrid.

All bio-stimulant treatments rose $\mathrm{N}, \mathrm{P}$ and $\mathrm{K} \%$ in the leaves over control in the two seasons.

The explanation in these criteria lies in the fact that all bio-stimulants induce plant uptake for nutrients necessary for plant growth and development accompanied with the enhancement of those enzyme activities responsible for vigorous growth of the plants as previously mentioned. The superiority for chitosan may be due to its role in the enhancement of nutrients uptake, reducing oxidative stress and its antifungal, antiviral and antibacterial properties as mentioned by Hadrami et al. (2010) and Hadwiger (2013).

Similar results were obtained by Kim et al. (2005) on basil, Nasiroleslami and Safaridolatabad (2014) on dill plants and Boshra A. El-Sayed et al. (2016) on Cycas plant.

The treatments gave significant increment in total alkaloids \%. Catharanthus roseus plant contains 130 bioactive terpenoid indole alkaloids, among which vinblastine and vincristine are regarded as the most important (Nejat et al., 2015). The above results are in agreement with those obtained by Qifang et al. (2010) who stated that salicylic acid treatment resulted in a significant increase of vinblastine, vindoline and catharanthrine of Periwinkle plants. Also Idrees et al. (2011) found that, total alkaloids content was improved by salicylic acid application in Periwinkle plants.

\section{Conclusion}

To obtain high quality plants with balanced chemical constituents and highest content of total alkaloids of periwinkle, the plants of 3 months old should be foliar sprayed with chitosan (a seaweed extract) at either 300 or 200 ppm (from the economic point of view) at fortnightly intervals commencing after two months from transplanting.

\section{REFERENCES}

[1] A. O. A. C. (1980): Official Methods of Analysis. 12th Ed. - Association of Official Analysis Chemists, Washington, DC.

[2] Bohme, M., Thi Lua, H. (1997): Influence of mineral and organic treatments in the rizosphere on the growth of tomato plants. - Acta Hortic 450: 161-168.

[3] Boogar, A. R., Shirmohammadi, E., Geikloo, A. (2014): effect of humic acid application qualitative characteristic and micronutrient status in Petunia hybrid L. - Bull. Env. Pharmacol. Life Sci. Col 3(9): 15-19.

[4] Cacco, G., Dell Agnolla, G. (1984): Plant regulator activity of soluble humic substances. - Can. J. Soil Sci. 64: 25-28.

[5] Calvo, P., Nelson, L., Kloepper, J. W. (2014): Agricultural uses of plant biostimulants. Plant Soil. 383: 3-41. DOI: 10.1007/5 11104-014-2131-8. 
[6] Castro, Q. T., Avelelas, F. P., Leandro, S. (2016): Chitosan seed soaking: germination and growth of coriandrum sativum and Solanum bycopersicum. - Front. Mar. Sci. Conference Abstract, International Meeting on Marine Research, Peniche, Portugal. DOI: 10.3389/conf.

[7] Chapman, H. D., Pratt, P. F. (1978): Methods of Analysis for Soils, Plants and Waters. Univ California Div. Agric. Sci, Oakland, pp. 12-19.

[8] El-Khateeb, M. A., Nasr, A. A., Fahmy, A. N., Dorgham, A. H. (2010): Effect of GA3 and growth bio-stimulants on growth and chemical composition of Calia secundiflora plants. - J. Horti. Sci. and Ornamental Plants 2(2): 118-124.

[9] El-Khateeb, M. A., El-Adaawy, A. E., Saber, A. A. (2018): Growth and quality of Spathiphyllum wallisii L. plants as affected by foliar sprays of algae, chitosan, atomic and humic acid. - Bio-Sci. Res. 15(2): 618-627.

[10] El-Sayed, B. A., Noor El-Deen, T. M., Abdel-Galeil, L. M., Aly, W. A. (2016): Effect of natural activator (BIOHORM) and humic acid on growth and quality of Cycas plant. Scientific J. Flowers \& Ornamental Plants 3(1): 79-86.

[11] Gad, M. M., Abdul-Hafeez, E. Y., Ibrahim, O. H. M. (2016): Foliar application of salicylic acid and gibberellic acid enhances growth and flowering of Ixora coccinea L. plants. - J. Plants Production, Mansoura Univ. 7(1): 85-91.

[12] Guan, Y., Jin, H., Xian, W., Chenia, W. (2009): Seed priming with chitosan improves maize germination and seedling growth in relation to physiological changes under low temperature stress. - J. Zhejiang Univ. Sci. 10: 427-433.

[13] Hadrami, A. E., Adam, L. R., Hadrami, I. E., Daayf, F. (2010): Chitosan in plant protection. - Mar. Drugsoy 8: 968-987.

[14] Hadwiger, L. A. (2013): Multiple effects of chitosan on plant system: solid science of hype. - Plant Sci. 20(8): 42-49.

[15] Harridy, M. A. I. (1986): Physiological studies on periwinkle plant Catharanthus roseus G. Don. - Ph. D. Thesis. Fac. Agric., Cairo University.

[16] Idrees, M., Naeem, M., Aftab, T., Khan, M., Moinuddin, M. A. (2011): Salicylic acid mitigates salinity stress by improving antioxidant defence system and enhances vincristine and vinblastine alkaloids production in periwinkle (Catharanthus roseus). Acta Physiologiae Plantarum 33(3): 987-999.

[17] Jackson, M. L. (1973): Soil Chemical Analysis. - Prentice Hall of India Private Limited, New Delhi.

[18] Kim, H. J., Chen, F., Wang, X., Rajapakse, N. C. (2005): Effect of chitosan on the biological properties of sweet basil (Ocimun basilicum L.). - J. Agric. Food Chem. 53(9): 696-701.

[19] Krishnan, P., Ravi, I., Nayak, S. K. (1996): Methods for determining leaf chlorophyll content of rice: a reappraisal. - Ind. J. Experim. Bio. 34: 1030-1033.

[20] Mahdavi, B. (2013): Seed germination and growth responses of isabgol (Plantago ovata Forsok) to chitosan and salinity. - Inter. J. Agric. and Crop Sci. 5(10): 1084-1088.

[21] Malekpoor, F., Pirbalouti, A. G., Salami, A. (2016): Effect of foliar application of chitosan on morphological and physiological characteristics of basil under reduced irrigation. - Res. on Crops 17(2): 354-359.

[22] Masoud, A. N., Sciuchett, I. A., Farnsworth, N. R., Blomste, R. N., Meer, W. A. (1968): Effect of gibberellic acid on growth of Catharanthus roseus. - J. Pharm. Sci. 57: 589593.

[23] Nasiroleslami, E., Safaridolatabad, S. (2014): The comparison of organic and biologic fertitilizers effects on growth and essential oil of dill (Anthum gravcolens L.). - Inter. J. Biosciences 5(7): 65-74.

[24] Nejate, N., Valdiani, A., Cahill, D., Tan, Y. H., Maziah, M., Abiri, R. (2015): Ornamental exterior versus therapeutic interior of Madagascar periwinkle (Catharanthus roseus): the two faces of a versatile herb. - The Scientific World Journal. DOI: 10.1155/2015/982412. 
[25] Qifang, P., Yu, C., Quan, W., Fang, Y., Shihai, X., YueSheng, T., Jing Ya, Z., Xiaofen, S., Kexuan, T. (2010): Effect of plant growth regulators on the biosynthesis of vinblastine, vindoline and catharanthine in Catharanthus roseus. - Plant Growth Regulation 60(2): 133-141.

[26] Russo, R. O., Berlyn, G. P. (1990): The use of organic bio-stimulants to help low input sustainable agriculture. - J. Sustain. Agric 1: 19-42.

[27] Salachna, P., Byczynska, A., Jezziorska, I., Udycz, E. (2017): Plant growth of Verbena bonariensis L. after chitosan gellan gum or iota carrageenan foliar application. - World Scientific News 62: 111-123.

[28] Steel, R. G. D., Torrie, J. H. (1980): Principles and Procedures of Statistics. - McGrawHill Book Co., Inc., New York, pp. 377-400.

[29] Volt, A. C., Dempsey, D. A., Klessing, D. F. (2009): Salicylic acid, a multifaceted hormone to combat disease. - Annual Review of Phytopathology 47: 177-206. 